\title{
Self-governing prisons: Prison gangs in an international perspective
}

\author{
Michelle Butler ${ }^{1}$ (D) Gavin Slade ${ }^{2}$. \\ Camila Nunes Dias ${ }^{3}$
}

Published online: 30 March 2018

(C) The Author(s) 2018

\begin{abstract}
This paper finds qualified support for the use of Skarbek's (2011, 2014) governance theory to understand the emergence of prison gang-like groups in Kyrgyzstan, Northern Ireland and Brazil. However, Skarbek's $(2011,2014)$ governance theory has little to say about how many prison gangs emerge and how they organise comparatively outside the US context. This paper argues that variation in the number of gangs and their monopolization of informal governance can only be explained by considering importation and deprivation theories alongside governance theories. These theories factor in variation in prison environments and pre-existing societal divisions imported into prison, which affect the costs on information transmission and incentives for gang expansion. In particular, the paper pays attention to the wider role social and political processes play in influencing whether monopoly power by prison gangs is supported and legitimized or not.
\end{abstract}

Keywords Prison gangs · Brazil · Northern Ireland $\cdot$ Kyrgyzstan · Prison governance Monopoly Power · Gang Consolidation

Increasing attention has been paid to the problem of prison gangs, with much of this literature focusing on prison gangs in the US (Camp and Camp 1985; Fleisher and Decker 2001; Skarbek 2011, 2014; Winterdyk and Ruddell 2010). Yet, such groups are far from a US phenomenon. Studies highlight the existence of such groups in South

Michelle Butler

michelle.butler@qub.ac.uk

1 School of Social Sciences, Education \& Social Work, Queen's University of Belfast, 6 College Park, Belfast BT7 1LP, UK

2 School of Social and Political Sciences, University of Glasgow, Glasgow, UK

3 Centre for Engineering, Modelling and Applied Social Sciences, Federal University of ABC, Santo André, São Paulo, Brazil 
Africa (Steinberg 2004), Brazil (Dias and Darke 2016), and Russia (Oleinik 2003). Nevertheless, few papers have questioned the extent to which insights from the US can be applied to other jurisdictions. By using Skarbek's $(2011,2014)$ governance theory to examine the exportability of insights from the US to Kyrgyzstan, Northern Ireland and Brazil, this paper seeks to highlight how our theoretical understanding of the development, formation and structure of such groups can be enhanced by embracing a comparative perspective. The paper argues that while Skarbek's $(2011,2014,2016)$ governance theory can offer useful insights into our understanding of when such groups emerge, deprivation and importation theories are important for explaining differences in the number of gangs and their ability to monopolise informal governance. By examining the wider socio-political context in varied jurisdictions, as well as the resourcing and penal architecture used, this paper demonstrates how deprivation and importation theories should be considered, alongside governance theories, to understand variation in the fragmentation of gangs and their consolidation.

\section{Gangs and governance: regulating prison society}

Despite the growth in prison gang research, there continues to be a lack of an internationally agreed upon definition of what constitutes a prison gang (Aldridge et al. 2012; Medina et al. 2013; Smithson et al. 2012; Weerman et al. 2009). Lyman (1989: 48) has defined a prison gang as a "self-perpetuating criminally oriented entity, consisting of a select group of inmates who have established an organized chain of command and are governed by an established code of conduct". Other definitions focus on the number of people involved, their origination in the prison system and the extent to which their activities pose a threat to institutional safety and order (Knox 2005; Wood 2006; Winterdyk and Ruddell 2010). Skarbek (2014) likewise emphasises the selective nature of prison gang membership, gang existence as a corporate entity, organised hierarchical structure, recruitment of members from the prison population and widespread involvement in criminal behavior. For the purposes of this article, we accept this latter characterisation of what a prison gang is while noting that politicized prison gangs, such as those we discuss in Northern Ireland, dispute the criminality of their activity.

Two main theoretical approaches that are important for explaining prison gangs have been used to understand behavior more broadly in prison: the importation and deprivation models. The deprivation model argues that the peculiarities of the prison environment create 'pains' or deprivations that uniquely shape prison behavior and can lead people to behave differently in prison compared to the outside world (Sykes 1958). These deprivations shape prison social norms, resulting in an 'inmate code' which can be used to govern prisoner interactions (Sykes 1958; Sykes and Messinger 1960). In contrast, the importation model argues that behavior should be understood by examining the individual characteristics, pre-prison experiences and social norms that prisoners import into prison with them (Irwin and Cressey 1962).

With regard to prison gangs, importation theory tends to emphasize the societal role gang culture and street gang structures play in shaping prison gangs (Irwin 1980; Wacquant 2001; DeLisi et al. 2011; Jacobs 1974, 1977; Pyrooz et al. 2011). According to Sãnchez-Jankowski (2003), gangs cannot be understood without understanding the 
wider societal socio-economic, political and historical context, as gangs grow and develop in response to social change. Some have argued further that prison gangs are very similar to street gangs (Maxson 2012; Pyrooz et al. 2011). Recent research confirms that prison gangs share beliefs, characteristics and activities with street gangs but variations in gang membership are evident (Decker 2018; Mitchell et al. 2018). Prison gang members are not always street gang members and they vary in the extent to which they continue to be active gang members upon their release (Decker 2018; Mitchell et al. 2018). These findings suggest that prison and street gangs can exist independently of each other and that theories used to understand behavior in the community may not always be directly transferrable to prison.

Indeed, as opposed to emphasizing imported behavior, deprivation theory claims that involvement in prison gangs is due to the particular pains experienced in prison. For instance, the fear of victimization, the limited means by which to demonstrate status and the restricted access to goods are believed to be common deprivations that lead people to join prison gangs (Lessing 2017; Skarbek 2014; Winterdyk and Ruddell 2010). Yet while some have raised questions about the extent to which gang involvement is linked to status in prison (Kreager et al. 2017), the desire to integrate, obtain status, belong and be protected, as well as to facilitate trade, are common explanations given by gang members for their gang involvement (Decker 2018). Similar to prison behavior more generally, it has also been argued that both deprivation and importation theories are required to understand prison gangs (Crewe 2009; Cunha 2014; Mitchell et al. 2017).

Skarbek $(2014,2016)$ questions the usefulness of the importation and deprivation models, stating that the empirical evidence for the importation theory is weak and that deprivation theory posits an invariant prison experience and prisoner identity that cannot explain variation in gang emergence. Instead, Skarbek $(2014,2016)$ proposes that prison gangs emerge in prison populations in which decentralized mechanisms of governance, such as an inmate code, cannot be relied upon or when prison officials do not provide adequate governance. When attempting to explain the growth of US prison gangs, Skarbek $(2011,2014,2016)$ finds that a rapidly growing US prison population, combined with increasing numbers of younger and drug using prisoners, led to a breakdown in the inmate code and a growing demand for governance among prisoners. Skarbek $(2014,2016)$ theorizes that this demand is met by prison gangs which provide governance by regulating prisoner interactions, thereby enabling trade. Skarbek $(2014,2016)$ argues that prison gangs act as a community responsibility system; groups are held responsible for the actions of their individual members and so gangs have an interest in policing member behaviour in order to manage reputation and facilitate trade with other groups (Skarbek 2014, 2016).

In a recent article, Skarbek (2016) tests his theory on a range of jurisdictions - the US, Brazil, Bolivia, the UK and Sweden. The article argues that where the demand for governance is met by prison authorities centralized prison gangs do not emerge; that in smaller prison populations governance is decentralized; that ethnic heterogeneity produces a problem for inmate governance only in larger prison populations; and that varying costs on information transmission and incentives for expansion determine whether centralized governance structures emerge.

Skarbek's (2016) finds centralized inmate governance structures - gangs - in Bolivia, Brazil and the US. However, Skarbek (2016) says nothing more about the 
number of these gangs other than that they are centralized structures and, due to the number of prisoners in some cases, such as the US, they divide up for coordination purposes along racial or ethnic lines. Yet, Skarbek (2014) has commented in previous work that it is unusual to have multiple providers of governance as protection markets have a tendency towards monopoly (see Schelling 1971; Tilly 1985; Reuter 1983; Gambetta 1993; Varese 2010). Skarbek (2016) acknowledges that Brazilian inmate governance exhibits monopoly (see Darke 2013) whereas US gangs are highly differentiated. To explain the number of gangs in a given jurisdiction, Roth and Skarbek (2014) argue that while prison gangs aim to capture economies of scale by growing in size, the costs of internal organization provide a brake on prison gang expansion. They propose that race and ethnicity are exogenous attributes that can be used to fragment excessively large gangs, consolidate excessively small gangs and reduce the costs associated with monitoring gang members by facilitating internal cohesion and solidarity. Moreover, just as gangs have incentives to restrict size, Roth and Skarbek (2014) theorize that prison administrators also have an optimal number of gangs that they prefer to deal with, which influences the number of gangs in a prison system. The number of gangs and their racialization in the US case is, for Roth and Skarbek (2014), a function of these factors.

This paper seeks to focus on this specific problem of prison gang numbers, that is the fragmentation and consolidation of prison gangs, utilizing cases outside the US. The paper employs a comparative case study design, taking cases where gangs are present in every case but where these gangs represent significant variation in terms of number and the monopolization of governance functions. The paper draws on three case studies from Kyrgyzstan, Brazil and Northern Ireland. These case studies represent a convenience sample - the authors research these jurisdictions - but they also demonstrate significant variation in inmate governance provision across extremely different jurisdictions. We argue that in our cases this variation cannot be explained without reference to importation and deprivation theories.

In terms of deprivation, many authors have highlighted how the conditions in prison can vary substantially between prison systems and across different prisons in the same prison system, depending on the culture, resources and nature of staffprisoner interactions (Crewe 2009; Cunha 2014; Liebling 2004; Ugelvik and Dullum 2012). In this vein, we concentrate on variation in prison environments in terms of:

- architectural design of prison accommodation

- levels of resourcing

- overcrowding

- frequency of prisoner transfer from prison to prison

- formal and informal policies of prison segregation according to imported identities

These features can produce a varied prison experience that impacts not just whether prison gangs emerge but how many gangs emerge and how they organize. Following Skarbek (2016), we suppose these factors have important impacts on the costs on information transmission and the production of incentives and opportunities to expand. These mechanisms subsequently impact the probability of the emergence of centralized governance as well as the monopolization of that governance. 
In terms of importation, while this theory might not help explain variation in where gangs emerge, we are particularly interested in how the wider role of social and political processes outside prison can influence how monopoly power by prison gangs is supported and legitimized or not. In our cases, we concentrate on the following:

- political, ethnic and religious divisions

- collectivist and socio-economic class based ideologies

Our argument is that the market for governance provision in prison should in principle move towards monopoly due to economies of scale, similar to any other protection market (Schelling 1978; Tilly 1985; Gambetta 1993). Collective living arrangements, ${ }^{1}$ extreme under-resourcing and overcrowding, as well as frequent prisoner movement, can exacerbate the monopolization process across prisons. These environmental factors can produce the incentives and opportunities to develop stable and homogenized norms and informal structures (Kaminski and Gibbons 1994). However, identities from outside prison are imported and we argue that these either facilitate or hinder this process of monopolization. Identities based on wider class and socio-economic statuses may be more likely to entrench monopolies by producing commitment through pre-existing mutual attraction among prisoners, while wider and conflicting racialized, political or religious identities imported into prison may produce barriers to monopolization and facilitate a fragmented gang landscape.

Data on prison gangs is extremely limited even in the US case, and this poses a significant problem for this paper. We utilise first-hand accounts from interviews with prisoners, prison staff and experts as well as secondary documentation to explore the issues introduced above. In each case, more data and research is needed. Causal connections cannot be established with high degrees of confidence and we thus offer this paper as a starting point for the comparative study of prison gangs globally. We now give brief outlines of the emergence and form of prison gangs and the degree of monopolization of the governance function in our three cases. In the final discussion section, we study what drives variation across our cases, bringing back in the elements of deprivation and importation theories put forward above.

\section{Kyrgyzstan $^{2}$}

There are some 10,000 prisoners in the Kyrgyz prison system (166 per 100,000), with most of these prisoners held in prison 'colonies' (ICPR 2017). The architecture of these colonies is based on the use of large, communal dormitories left over from the Soviet Union. $^{3}$ The relatively large size of the prison population is maintained by punitive sentencing practices that have not changed much since Soviet times, with long sentences of up to 5 years given for minor crimes. Over a third of prisoners are aged under 30, with

\footnotetext{
${ }^{1}$ We use the term collective living arrangements to refer to prison buildings that have been deliberately designed to house prisoners in large dormitories rather than in individualised cells or cells holding small numbers of individuals.

${ }^{2}$ The information presented in this section is based on 33 in-depth interviews by one of the authors with former prisoners $(n=20)$, prison guards $(n=5)$, government and non-government practitioners $(n=8)$.

${ }^{3}$ Kyrgyzstan attained sovereignty as a nation-state only after the break-up of the Soviet Union in 1991.
} 
the remainder aged between 30 and 55 (UNDOC 2012). Ethnic minorities, drawn from the significant groups of Uzbeks, Russians and Kazakhs in the country, are also overrepresented in the criminal justice system (US Department of State 2016).

The collapse of the Soviet Union left the Kyrgyz state in a weakened position to provide basic social services and resources to run the prison system. For instance, in 2005 , the prison department's budget could provide for only $26 \%$ of the prison estate's needs (International Crisis Group 2006), this had risen to only 35\% by 2016 (Public Defender's Office of Kyrgyzstan 2016). The government spends only $\$ 1000$ USD per year per prisoner on the prison system. As a result, prisoners tend to be reliant on each other for food, support, security and the physical maintenance of their environment. There is insufficient prison staff employed to meet the needs of those imprisoned and pay for prison staff is low, contributing to high levels of corruption (Engvall 2016).

In this context, gangs that emerged in the Soviet period have gained great prominence. One particular group of prisoners, the vory-v-zakone or 'thieves-in-law', dominates the others. Below the vor-v-zakone is the polozhenets (leader), then the smotryashchie (supervisors or deputies), muzhiki (workers) and then the opushennie (outcasts). These prisoner hierarchies exist across all of Kyrgyzstan's eleven prison colonies, as well as its remand prisons (Kupatadze 2014). Vory monopolize informal governance through their appointed prison leaders. They network with each other, monopolize decision-making about positions in the caste system, have the exclusive right to make decisions on punishment, as well as communicate informal rules through both word of mouth, and, after the collapse of the Soviet Union, through written documents circulated in the remand system.

The vory existed across the Soviet Gulag camp system. Three main conditions gave rise to their formation and dominance at the beginning of the 1930s. Firstly, there was incredible flux in the prison population in the 1920s and early 1930s. The turnover destabilised prisoner social norms and relationships (Viola 2007; Barnes 2011; Varese 2001). Secondly, at this time the number of people imprisoned grew quickly. There was limited governance provided by prison officials (Viola 2007; Barnes 2011). Thirdly, the new communist regime encouraged a collectivist culture through its use of communal prison architecture and promotion of collectivist social norms (Kharkhordin 1999; Piacentini and Slade 2015). Prisoners were required to live in large communal dormitories, with little privacy, and engage in mutual peer surveillance. It was in these conditions that the vory were formed and rose to power as they were utilized by the prison authorities to maintain order and police the other prisoners in the open spaces of the camps (Viola 2007; Barnes 2011).

This demand for governance by prisoners continues in Kyrgyzstan today. In the Kyrgyz prison system, there are a small number of vory that monopolise governance functions through the polozhentsi and smotryashchie (Cowley et al. 2015; Kupatadze 2014). Resources are pooled and redistributed across the entire prison system through a fund known as the obshchak, overseen by the vory. A large market for various foodstuffs, medicines, cigarettes and drugs exist. This market is regulated by the vory utilizing the obshchak and informal courts known as skhodki (International Crisis Group 2006; Moller et al. 2008). The vory oversee the taxing and regulation of this trade and utilize an informal code known as the 'understandings' to govern prisoner social interactions. The vory also resolve prisoner conflicts and enforce symbolic and social boundaries between prisoners. 
Kyrgyz prisoner groups are not divided along racial lines despite the ethnic diversity of the Kyrgyz prison population. Any ethnicity can become a vor and the vory are a diverse group drawn from a range of different ethnicities. Tattoos rather than ethnicity are used to identify the vory, with the use of these tattoos being strictly policed. The social and symbolic boundaries of the vory are organized around class and relations with the state. Vory cannot be political prisoners, an important distinction in Soviet times, and must have no relationship with the state. This means that vory and their adherents cannot work or have worked outside prison.

\section{Northern Ireland ${ }^{4}$}

In Northern Ireland, paramilitary groups are the strongest 'gangs' inside prison and outside prison (see Hamill 2011; McEvoy 2001). These paramilitaries groups are primarily delineated on political and religious lines, with some seeking a return to a United Ireland and others seeking to protect the Union with Great Britain (McEvoy 2001). These groups were exported from the community into the prison system and their influence on the prison system waxed and waned depending on the wider political, social and economic climate (McConville 1981, 2014). The influence of imprisoned paramilitary groups was especially strong during the conflict (19681998) (McEvoy 2001).

Paramilitary groups began to dominate the prison system following the outbreak of the conflict, as prison authorities struggled to deal with the dramatic increase in the prison population, arising from a political decision to detain large sections of the population to reduce civil unrest and disorder (Gardiner 1975; McKeown 2001; Smith 2014). The average daily prison population increased from 617 in 1969 to 2517 in 1974 (Gardiner 1975; NIPS 1970, 1972). Most people were under 30, white, interned or imprisoned for rioting, assault, disorderly conduct, breaking and entering, and larceny, with the majority of those sentenced serving under 9 months (NIPS 1970, 1972). Staffing and accommodation were inadequate to cope with this rapid increase (Gardiner 1975). As a result, a disused airfield was converted into a detention camp and a staff recruitment campaign and prison building program was undertaken (Butler 2016; Gardiner 1975; Smith 2014). The detention camp was called Long Kesh (though later its name was changed to the Maze prison) and paramilitary groups were housed in separate communal compounds (McKeown 2001; Smith 2014). Each compound held up to 90 people, consisting of three Nissen hut dormitories (Gardiner 1975).

By $1975,71 \%$ of all imprisoned men were detained in these dormitories, with minimal contact with staff (Gardiner 1975). Most staff were also inexperienced and had limited, if any, training (Butler 2017). As a result, paramilitary members took advantage of this governance gap to form an organizational structure which mirrored

\footnotetext{
${ }^{4}$ The claims made in this section are based on an analysis of government publications (Gardiner 1975; NIPS 1970, 1972; Hennessey, 1984; House of Commons Northern Ireland Affairs Committee 2003; Prison Review Team 2011; CJINI 2015) research studies (McConville 1981, 2014; McEvoy 2001; Conflict in Cities 2007; Gregory et al. 2013; Butler 2016, 2017) and prisoner autobiographies (Green 1998; McKeown 2001; Smith 2014). These sources have been referenced throughout.
} 
paramilitary groups within the community (Butler 2017; McKeown 2001; Smith 2014). Due to a lack of training and staff shortages, prison staff mostly 'turned a blind eye' to the power these groups were amassing so long as they helped to maintain order and control (McKeown 2001; Smith 2014).

In 1972, a political decision was taken to recognize the differences in these paramilitary prisoner groups and they were allowed to self-govern and were held separately to other prisoners (Butler 2017; Gardiner 1975; McEvoy 2001). This decision was taken as the Northern Ireland government sought to agree a cessation to the conflict, working with paramilitary groups in the community to organize a ceasefire (Butler 2017; McEvoy 2001). When these attempts failed, the government decided to reverse this decision, arguing that it lessened staff control and strengthened the influence and control of paramilitary groups in prison (Butler 2017; McEvoy 2001). From 1976, these groups were no longer to be treated differently, housed separately or allowed to self-govern (Butler 2017; McEvoy 2001). A new cellular prison (Maghaberry prison) was built to try to lessen the control of paramilitaries and 20 prison staff were murdered by paramilitaries in the community in retaliation (Butler 2016; McEvoy 2001).

In prison, paramilitaries continued to resist this change in government policy and engaged in a hunger strike to motivate public and political support for their cause (Butler 2016; McEvoy 2001). In 1981, the government conceded limited free association to paramilitaries groups in response to the national and international public support they had garnered in response to their hunger strike (Butler 2017; McEvoy 2001). It was publicly argued that it was unrealistic to expect such groups to integrate with each other in prison when Northern Ireland society was marred with division, sectarianism and conflict (Conflict in Cities 2007; Gregory et al. 2013).

After 1981, paramilitary groups continued to maintain their self-governance structures through the use of intimidation and condition (Green 1998; Hennessey 1984; McKeown 2001). Intimidation was used to condition non-paramilitary prisoners and staff to avoid entering certain prison locations, ensuring these groups remained powerful and self-governing, despite being held in a cellular prison with greater security and more prison staff (Hennessy 1984). Prison staff also felt betrayed by government officials after they decided to grant limited free association to these groups after their hunger strike (Butler 2017; McEvoy 2001). These feelings resulted in some staff failing to challenge the behavior of paramilitary groups as they believed that the government was appeasing paramilitary groups in prison to find a political resolution to the conflict in Northern Ireland (Butler 2017; Hennessy 1984). These experiences contributed to prison managers feeling they lacked the political support to adopt novel strategies to address the challenges these groups posed to the prison system (Butler 2017; McEvoy 2001; Prison Review Team 2011).

As recently as 2003, government officials again decided to recognize these groups as different and house them separately to the rest of the prison population, against the advice of prison officials who feared that such a move would increase the influence and power of these groups as it had done in the past (House of Commons Northern Ireland Affairs Committee 2003). Today, these groups continue to be held separately, resulting in significant security, legitimacy and resourcing challenges for prison staff, and the management of these groups remains a divisive political topic, subject to ongoing political debate (Butler 2017; CJINI 2015; Prison Review Team 2011). 


\section{Sao Paulo - Brazil ${ }^{5}$}

In Brazil, the existence of prison gangs is a relatively recent phenomenon, dating from the end of the 1970s. The first group to be publicly known about and recognized as such was the Comando Vermelho (CV - Red Command) at the Ilha Grande Penitentiary (Rio de Janeiro state) in 1979 (Amorim 2005; Coelho 2005). The creation of the $\mathrm{CV}$ is largely attributed to the shared experiences of political and ordinary prisoners, and their willingness to work together to seek improvements in their prison conditions (Amorim 2005; Coelho 2005). Political prisoners taught the ordinary prisoners how to organize to promote solidarity and use collective action to achieve their goals (Amorim 2005; Coelho 2005). These political prisoners were arrested because they were believed to be a threat to the Brazilian military government that came to power as a result of the 1964 coup d'état by the Armed Forces (Amorim 2005; Coelho 2005).

Nevertheless, it was not until 1993, that the first prison gang is believed to have formed in the São Paulo prison system. This group called itself the Primeiro Comando da Capital (PCC - First Command of the Capital) (see Dias and Salla 2013). São Paulo has by far the largest number of prison establishments (168 facilities currently) and close to 240,000 prisoners (Justice Ministry 2017). It holds one-third of Brazil's prison population and, for this reason, events in São Paulo generally take on national importance (Justice Ministry 2017). This population is majority male (95\%), young (53\% under 29 years old), black $(56 \%)$ and sentenced up to 15 years (80\%) (Justice Ministry 2017). Prison staff are greatly outnumbered by prisoners and are largely absent from the everyday life of prisoners, leaving prisoners to manage their own interactions and conflicts. Overcrowding is also common, resulting in most prisoners living in large communal prison buildings with little oversight by prison staff. This absence of governance by prison officials provided the PCC with an opportunity to amass power and influence in the prison system.

The influence of the PCC quickly spread throughout the entire São Paulo prison system and other Brazilian states, making it one of the most widely recognized prison gangs in Brazil. Its influence also spread from the prison system to the wider community, allowing the PCC to control and regulate a range of criminal activities in both prison and the community, making it a key player in the Brazilian criminal economy. The PCC has achieved a dominance unrivalled by other gangs (Dias and Darke 2016). However, the PCC would have been unable to obtain this level of dominance if they had relied solely on the threat of physical violence to cower other potential rival groups into submission (Dias and Darke 2016). Instead, the PCC sought to strengthen and consolidate its power by suppressing divisions and producing a cohesive and unifying identity among the prison population. This is evident from PCC documents in which they emphasize the importance of striving for unity, peace, equality, liberty and justice (Alvarez et al. 2013). For example, item 2 of the PCC statute reads:

"Item 2: [it is the duty of brothers to] Always struggle for PEACE, JUSTICE, LIBERTY, EQUALITY, and UNITY, seeking always the growth of the organization, and always respecting the criminal ethic."

\footnotetext{
5 The information presented in this section is based on previous research by one of the authors, which included in-depth interviews with 40 former prisoners in several prisons in Sao Paulo, Brazil, interviews with prison guards and a review of official documents, including police reports and court lawsuits.
} 
Accordingly, the PCC's dominance has been willingly co-produced by ordinary prisoners. Building on the legacy of solidarity and collective action that political prisoners taught ordinary prisoners, the PCC have promoted an ideology which emphasizes unity among the São Paulo prison population. They emphasize the shared experience of the 'pains' of imprisonment and use this shared experience to promote unity and collective action. In this way, the PCC seek to legitimate their organization and actions by emphasizing their desire to work together to overcome the deprivations all prisoners experience. Consequently, the PCC is continuously seeking to overcome differences and avoid fragmentation by building (albeit in an arbitrary and authoritarian way) a consensus among prisoners and using this consensus to improve their conditions. By legitimating itself in this way, the PCC has sought to encourage ordinary prisoners to accept its dominance and willing adhere to its social norms, policing activities and punishments without the significant use of force (Dias and Salla 2013).

As such, the PCC does not seek to directly involve itself in trading per se but rather acts as a resolver of disputes, a provider of protection or a facilitator (Dias 2013; Dias and Darke 2016). For example, the PCC resolve conflicts arising among sellers and between sellers and buyers through the adoption of a mechanism called 'debates' (Dias 2013). These 'debates' mirror the workings of the formal courts, allowing individuals to present their case and call witnesses before a decision is made on whether they have transgressed prisoner social norms and should be punished. The adoption of this mechanism has dramatically reduced violence within the São Paulo prison system, contributing to a marked drop in prisoner homicides (Dias and Salla 2013; Dias and Darke 2016).

\section{Discussion}

The overviews of our cases demonstrate some support for Skarbek's $(2014,2016)$ main thesis that prison gangs emerge during times of significant prison population growth and when prison officials cannot be relied upon to provide quality governance. Gang emergence in 1930s Soviet Union, 1970s Northern Ireland and 1990s Brazil all involved quick and large increases in the prison population, overcrowding, growing numbers of young people incarcerated and the insufficient provision of governance by prison officials. The growth of drugs and drug offending prisoners was most prevalent in the case of Brazil and does not seem to have been a necessary condition for gang emergence in the Soviet Union or Northern Ireland.

While gang emergence occurred across all cases, the number of gangs that persist in each case varies: Kyrgyzstan and Brazil demonstrate relatively monopolistic and consolidated, if contested, informal governance, while Northern Ireland produced a plurality of stable and fragmented gang entities along religious and political lines. In the US, there is racial fragmentation of gangs. We argue that it is necessary to draw on importation and deprivation theories to understand this variation in the consolidation and fragmentation of gangs once they have emerged - something that governance theory has less to tell us about comparatively outside the US context.

In terms of deprivation theory, where the prison environment pushes down the costs on information transmission and incentivizes gang expansion we expect consolidated gangs to emerge (Kaminski and Gibbons 1994; Skarbek 2016). Freer information flow lowers monitoring costs and enables expansion (Gambetta 2011). Information flow is 
less costly when prisoners live in collective conditions and in high corruption contexts where mechanisms of information transmission - mobile phones for example - are rife. Moreover, high turnover through the prison estate both enables information flow and incentivizes the creation of homogenous, monopolistic structures; prisoners do not wish to re-establish themselves in a new gang every time they move (Kaminski and Gibbons 1994; Gambetta 2011). In addition, variation in levels of staffing and resources can explain the varying incentives of prison authorities to intervene and fragment dominant gangs. Where resources are lower and corruption higher, staff are more likely to be coopted and to enable powerful established groups to embed a monopoly (Reuter 1983). This is particularly true if there are few architectural resources to manage fragmented gangs, such as reliable forms of spatial segregation.

Our cases lend support to such suppositions. In Kyrgyzstan and Northern Ireland, prison gangs emerged during historical periods when the prison population soared and prisoners were warehoused in collective living conditions - Soviet colony 'barracks' and the Nissen hut dormitories used during internment respectively. In Kyrgyzstan today, there is simply no architectural resource within one prison that would enable spatial segregation of fragmented gangs. While Brazilian prisons are formally cellbased, occupancy rates of approximately $173 \%$ (ICPR 2018a) mean that living conditions are intensely collective. Overcrowding is not such a huge problem in the US as occupancy rates are approximately 104\% (ICPR 2018b), and collective living and prisoner self-governance was not embedded in the institutional design as it was in Kyrgyzstan and Northern Ireland historically. ${ }^{6}$ Furthermore, Kyrgyzstan and Brazil represent exceptionally high corruption contexts with exceptionally low levels of staffing and resources. The government spend per prisoner per year in 2016 in Kyrgyzstan was $\$ 1000$ USD compared to $\$ 40,000$ USD per prisoner in the US (Public Defender's Office of Kyrgyzstan 2016). In Brazil, in some prisons at certain times of the day staff to prisoner ratios extend to 1:137 (King and Valensia 2014). Our respondents also reported the prevalence of mobile phones in Kyrgyz and Brazilian prisons, significantly lowering costs on information flow and enabling prison gang reach.

Northern Ireland, where consolidation did not occur, had higher levels of staffing and resources after the internment policy of the 1970s, relative to our other cases. Communal prison conditions that may have increased the probability of the emergence of consolidated informal prison governance was mediated by the expansion of a cellbased system and the systematic segregation of paramilitary groups that, consequently, gave credence to paramilitary affiliation and religious distinction. This is reminiscent of certain policies in states in the US that segregate prisoners by race (Goodman 2014).

In addition, Kyrgyzstan and Brazil are prison systems with high levels of prisoner transfer. The vory's ascendancy in Soviet camps coincided with massive turnover in the Gulag system (Bacon 1994). In Kyrgyzstan today, the prison system is highly centralized with prisoners being moved in and out of the central remand prison in the capital city Bishkek frequently, whether to be transferred for segregation purposes or to attend

\footnotetext{
${ }^{6}$ The occupancy figures are based on the average occupancy rates for both the US and Brazil but we acknowledge that there can be significant variation between different states in each country and that overcrowding can result in individuals sharing a cell and spending a large porportion of their time in the company of others. However, in the US, prisons were largely designed with the intention of housing prisoners in individualised cells or cells holding a small number of people rather than the large dormitories that were deliberately built in Northern Ireland and Kyrpgystan.
} 
court. The power of the PCC has also been linked to turnover of its members around the Brazilian prison estate (Biondi 2017). Certain sources suggest that transfer is also frequent in the US and Northern Ireland also (Skarbek 2011; Williamson 2015; Department of Justice Northern Ireland 2016). Thus, it is entirely possible that the variation on this factor is not significant enough to explain differences. However, good data on frequency of prisoner transfer is hard to come by for the purposes of comparison so more research is needed in this area.

While the environmental factors above can incentivize or disincentivize fragmentation and consolidation, it is impossible to fully understand the variations in fragmentation and consolidation in our cases without reference to the importation of political, social, racial and economic divisions from wider society. Kyrgyzstan and Brazil have large and relatively diverse prison populations. Race and ethnicity might be expected to fragment gangs in these cases as they produce both obstacles to the coordination of informal governance as well as a convenient means to manage gang size (Roth and Skarbek 2014; Skarbek 2016; Decker and Pyrooz 2016). This fragmentation has not overtly occurred in Kyrgyzstan or Brazil. On the one hand, low costs on information transmission and strong incentives for expansion may overcome the impediment of ethnic diversity to consolidation. Moreover, such an impediment is anyway statistically weaker in Brazil and in Kyrgyzstan than in the US; Brazilian prisons are simply less ethnically fragmented than US prisons (Skarbek 2016).

Yet, just as importantly, in Kyrgyzstan and Brazil, ethnic distinctions have been deliberately smoothed by appeals to social and political values that were imported into prison. Collective culture and communal social norms evident in the Kyrgyz prison system are a lingering legacy of communism (Piacentini and Slade 2015), resulting in the tendency to repress nationalism or ethnic self-expression. Regional and ethnic identities in Kyrgyz prisons are therefore subordinated to the ethnicity-blind structure of the vory, precisely to avoid conflict that might naturally occur in a country which has experienced serious race riots between Kyrgyz and large Uzbek minorities recently. Similarly, in Brazil, it is difficult to explain the dominance of the PCC without reference to their socio-political context and ideological emphasis on unity, cohesion and solidarity.

In contrast, in Northern Ireland, political division produced through decades of armed struggle played a significant role in explaining a lack of consolidation or hegemony by any one group. While a demand for governance is clearly important to explain the existence of paramilitary groups in the prison system in Northern Ireland, the fact that they organized along military lines and legitimated themselves according to their relationship with the British government can only be explained through the importation of political and social ideologies. These divisions were entrenched by policies that institutionalized segregation according to religious and political affiliation. As Lessing (2017) argues efforts by the state to reduce the strength of these groups through segregation and repression has simply increased divisions and the power of paramilitaries in prisons and in communities, while at the same time undermining state authority and legitimacy.

Table 1 below summarizes this discussion. The table shows variables for the present day only. Theoretically, positive answers down the columns increase the probability of consolidated gang presence in a prison system. The table shows the relative importance of collective living - through institutional design or overcrowding - under-resourcing 
Table 1 Overview of present day variation in prison environments and imported divisions

\begin{tabular}{|c|c|c|c|c|}
\hline Features & Kyrgyzstan & Northern Ireland & Brazil & US \\
\hline Explicitly communal architecture & Yes & No & No & No \\
\hline Extreme overcrowding & No & No & Yes & No \\
\hline $\begin{array}{l}\text { Significant under-resourcing } \\
\text { and corruption }\end{array}$ & Yes & No & Yes & No \\
\hline High Prisoner Transfer Frequency & Yes & Yes & Yes & Yes \\
\hline $\begin{array}{l}\text { Economic status trumps racial } \\
\text { or religious identity }\end{array}$ & Yes & No & Yes & No \\
\hline $\begin{array}{l}\text { Unsegregated by ethnic, } \\
\text { racial or religious identity }\end{array}$ & Yes & No & Yes & No \\
\hline Monopolization of governance provision & Consolidation & Fragmentation & Consolidation & Fragmentation \\
\hline
\end{tabular}

and corruption, and the importation and institutionalization of politicized racial, ethnic and religious identities in relation to gang consolidation. The table should not be taken as exhaustive or showing clear causal connections. The aim here is to summarize the discussion and indicate theoretically salient variables related to deprivation and importation and their relationship with gang consolidation.

\section{Conclusion}

The case studies presented in this article highlight how deprivation and importation theories retain explanatory importance if we wish to understand not just why gangs emerge but why in some cases they consolidate and monopolise informal governance. While offering some support for governance theories such as Skarbek's (2011, 2014, 2016) goverance theory, these case studies re-emphasize the importance of ideological, political, societal, situational, and environmental factors in differentially shaping the formation and behavior of such groups. Further studies should investigate in more depth the prison environment's effects on information transmission and incentives for gang consolidation, as well as the role of external cleavages, including the effects of street gang structures, that when imported to prison impact the probability of this consolidation.

Open Access This article is distributed under the terms of the Creative Commons Attribution 4.0 International License (http://creativecommons.org/licenses/by/4.0/), which permits unrestricted use, distribution, and reproduction in any medium, provided you give appropriate credit to the original author(s) and the source, provide a link to the Creative Commons license, and indicate if changes were made.

\section{References}

Aldridge J, Medina-Ariza J, Ralphs R (2012) Counting Gangs: Conceptual and Validity Problems with the Eurogang Definition. In: Esbensen FA, Maxson CL (eds) Youth Gangs in International Perspective: Results from the Eurogang Program of Research. Springer, New York 
Alvarez MC, Salla F, Dias CN (2013) Das Comissões de Solidariedade ao Primeiro Comando da Capital em São Paulo. Tempo Social 25(1):61-82

Amorim C (2005) CV-PCC: A irmandade do crime. Record, Rio de Janeiro

Bacon E (1994) The Gulag at War: Stalin's Forced Labour System in the Light of the Archives. Palgrave MacMillan, Basingstoke

Barnes SA (2011) Death and Redemption: The Gulag and the Shaping of Soviet Society. Princeton University Press Biondi K (2017) Prison Violence, Prison Justice: The Rise of Brazil's PCC. NACLA Rep Am 49(30):341-346

Butler M (2016) Prisoners and Prison Life. In: Healy D, Hamilton C, Daly Y, Butler M (eds) The Routledge Handbook of Irish Criminology. Taylor and Francis, London

Butler M (2017) Using Specialised Prison Units to Manage Extremists: Lessons from Northern Ireland. Terrorism and Political Violence, Published Online 29 November 2017 http://www.tandfonline. com/doi/abs/10.1080/09546553.2017.1388791

Camp GM, Camp CG (1985) Prison Gangs: Their Extent, Nature and Impact on Prisons. Government Printing Office, Washington

CJINI (2015) Report on an Unannounced Inspection of Maghaberry Prison 11-22 May 2015. CJINI, Belfast

Coelho EC (2005) Oficina do diabo e outros estudos sobre criminalidade. Record, Rio de Janeiro

Conflict in Cities (2007) Belfast: City Profile. Queen's University Belfast, Belfast

Cowley A, Ryan CM, Dunn EC (2015) The Law, the Mafia, and the Production of Sovereignties in the Kyrgyz Penal System. Ab Imperio 2015(2):183-208

Crewe B (2009) The Prisoner Society: Power, Adaption and Social Order in an English Prison. Oxford University Press, Oxford

Cunha M (2014) The Ethnography of Prisons and Penal Confinement. Annu Rev Anthropol 43(2):217-233

Darke S (2013) Inmate governance in Brazilian prisons. The Howard Journal of Crime and Justice 52(3):272-284

Decker SH (2018) From the street to the prison and back again: the transmission of norms, groups and offending. Presentation at Queen's University Belfast, 29 January 2018

Decker S, Pyrooz D (2016) The Real Gangbanging is in Prison. In: Woodredge J, Smith P (eds) The Oxford Handbook of Prisons and Imprisonment. Oxford University Press, Oxford

DeLisi M, Trulson CR, Marquart JW, Drury AJ, Kosloski AE (2011) Inside the prison black box: toward a life course importation model of inmate behavior. International Journal of Offender Therapy and Comparative Criminology 55:1186-1207

Department of Justice Northern Ireland (2016) The Prison Population of Northern Ireland 2015-2016. Department of Justice Northern Ireland, Belfast

Dias CN (2013) PCC: Hegemonia nas Prisões e Monopólio da Violência. Saraiva, São Paulo

Dias CN, Darke S (2016) From dispersed to monopolized violence: Expansion and Consolidation of Primeiro Comando da Capital's Hegemony in Sao Paulo's Prisons. Crime Law Soc Chang 65:213-225

Dias CN, Salla F (2013) Organized crime in brazilian prisons: The Example of the PCC. International Journal of Criminology and Sociology 2:397-408

Engvall J (2016) The State as Investment Market: Kyrgyzstan in Comparative Perspective. Pittsburgh University Press, Pittsburgh

Fleisher MS, Decker SH (2001) An Overview of the Challenge of Prison Gangs. Correct Manag Q 5(1):1-9 Gambetta D (1993) The Sicilian Mafia: The Business of Private Protection. Harvard University Press, Harvard Gambetta D (2011) Codes of the Underworld: How Criminals Communicate. Princeton University Press, Princeton Gardiner L (1975) Report of a Committee to Consider, in the Context of Civil Liberties and Human Rights, Measures to Deal with Terrorism in Northern Ireland. HM Stationary Office, London

Goodman P (2014) Race in California's Prison Fire Camps for Men: Prison Politics, Space, and the Racialization of Everyday Life. Am J Sociol 120(2):352-394

Green M (1998) The Prison Experience - A Loyalist Perspective. Ex-Prisoners' Interpretative Centre, Belfast Gregory IN, Cunningham N, Elli PS, Lloyd CD, Shuttlerworth IG (2013) Troubled Geographies: A Spatial History of Religion and Society in Ireland. Indiana University Press, Indiana

Hamill H (2011) The Hoods: Crime and Punishment in Belfast. Princeton University Press, Princeton

Hennessy L (1984) Report of an Inquiry by HM Chief Inspector of Prisons into the Security Arrangements in HM Prison Maze. HM Stationary Office, London

House of Commons Northern Ireland Affairs Committee (2003) The Separation of Paramilitary Prisoners at HMP Maghaberry. The Stationary Office Limited, London

ICPR (2017) Kyrgyzstan - World Prison Brief Data. Available at http://www.prisonstudies.org/country/kyrgyzstan (Accessed: $19^{\text {th }}$ December 2017)

ICPR (2018a) Brazil - World Prison Brief Data. Available at http://www.prisonstudies.org/country/kyrgyzstan (Accessed: 19 ${ }^{\text {th }}$ March 2018) 
ICPR (2018b) United States of America - World Prison Brief Data. Available at http://www.prisonstudies. org/country/united-states-america (Accessed: $19^{\text {th }}$ March 2018)

International Crisis Group (2006) Kyrgyzstan's Prison System Nightmare, Asia Report N¹18, 16 Aug 2006. Available at http://www.refworld.org/pdfid/44e9a1f64.pdf (Accessed: $1^{\text {st }}$ May 2017)

Irwin J (1980) Prisons in Turmoil. Little, Brown and Company, Boston

Irwin J, Cressey D (1962) Thieves, Convicts and the Inmate Culture. Soc Probl 10:142-155

Jacobs JB (1974) Street Gangs Behind Bars. Soc Probl 21(3):395-409

Jacobs J (1977) Stateville: The Penitentiary in Mass Society. University of Chicago Press, Chicago

Justice Ministry (2017) National survey of penitentiary information. Available at http://www.justica.gov.br/news/ha726-712-pessoas-presas-no-brasil/relatorio_2016_junho.pdf/view (Accessed: $18^{\text {th }}$ December 2017)

Kaminski MM, Gibbons DC (1994) Prison subculture in Poland. Crime \& Delinquency 40(1):105-119

Kharkhordin O (1999) The Collective and the Individual in Russia: A Study of Practices. University of California Press, London

King RD, Valensia B (2014) Power, Control, and Symbiosis in Brazilian Prisons. South Atlantic Quarterly 113(3):503-528

Knox GW (2005) The problem of gangs and security threat groups in american prisons today: recent research findings from the 2004 prison gang survey. Available at http:/www.ngcrc.com/corr2006.html (Accessed: $1^{\text {st }}$ May 2017)

Kreager DA, Young JTN, Haynie DL, Bouchard M, Schaefer DR, Zajac G (2017) Where ‘Old Heads' Prevail: Inmate Hierarchy in a Men's Prison Unit. Am Sociol Rev 82(4):685-718

Kupatadze A (2014) Prisons, politics and organized crime: The case of Kyrgyzstan. Trends in Organized Crime 17(3):141-160

Lessing B (2017) Counterproductive punishment: How prison gangs undermine state authority. Ration Soc 29(3):257-297

Liebling A (2004) Prisons and their Moral Performance: A Study of Values, Quality and Prison Life. Oxford University Press, Oxford

Lyman MD (1989) Gangland. Charles C. Thomas, Springfield

Maxson CL (2012) Betwixt and Between Street and Prison Gangs: Defining Gangs and Structures in Youth Correctional Facilities. In: Esbensen FA, Maxson CL (eds) Youth Gangs in International Perspective: Results from the Eurogang Program of Research. Springer, New York

McConville S (1981) A History of English Prison Administration Volume 1 1750-1877. Routledge \& Kegan Paul, London

McConville S (2014) Irish Political Prisoners, 1920-1962: Pilgrimage of Desolation. Routledge, London

McEvoy K (2001) Paramilitary Imprisonment in Northern Ireland. Resistance, Management, and Release. Oxford University Press, Oxford

McKeown L (2001) Out of Time: Irish Republican Prisoners Long Kesh 1972-2000. Beyond the Pale Publications, Dublin

Medina J, Aldridge J, Shute J, Ross A (2013) Measuring gang membership in England and wales: A latent class analysis with eurogang survey questions. Eur J Criminol 10(5):591-605

Mitchell MM, Fahmy C, Pyrooz DC, Decker SH (2017) Criminal crews, codes and contests: differences and similarities across the code of the street, convict code, street gangs and prison gangs. Deviant Behavior 38(10):1197-1222

Mitchell MM, McCullough Jun, Wu K, Pyrooz DC, Decker SH (2018) Survey Research with Gang and NonGang Members in Prison: Operational Lessons from the LoneStar Project. Trends in Organised Crime

Moller LF, Van Den Bergh BJ, Karymbaeva S, Esenamanova A, Muratalieva R (2008) Drug use in prisons in Kyrgyzstan: a study about the effect of health promotion among prisoners. Int J Prison Health 4(3):124-133

NIPS (1970) Annual Report for the Northern Ireland Prison Service. HM Stationary Office, Belfast

NIPS (1972) Annual Report for the Northern Ireland Prison Service. HM Stationary Office, Belfast

Oleinik AN (2003) Organized Crime, Prison, and Post-Soviet Societies. Routledge, Ashgate

Piacentini L, Slade G (2015) Architecture and attachment: Carceral collectivism and the problem of prison reform in Russia and Georgia. Theor Criminol 19(2):179-197

Prison Review Team (2011) Review of the Northern Ireland Prison Service: Conditions, Management and Oversight of All Prisons. Prison Review Team, Belfast

Public Defender's Office of Kyrgyzstan (2016) Human Rights in Kyrgyzstan. Public Defender's Office of Kyrgyzstan, Bishkek

Pyrooz DC, Decker SH, Fleisher M (2011) From the street to the prison, from the prison to the street: understanding and responding to prison gangs. Journal of Aggression, Conflict and Peace Research 3(1):12-24

Reuter P (1983) Disorganized Crime: The Economics of the Visible Hand. MIT Press, Cambridge 
Roth MG, Skarbek D (2014) Prison gangs and the community responsibility system. Review of Behavioral Economics 1(3):223-243

Sãnchez-Jankowski M (2003) Gangs and social change. Theor Criminol 7(2):191-216

Schelling TC (1971) What is the Business of Organized Crime? The American Scholar 40(4):643-652

Skarbek D (2011) Governance and Prison Gangs. American Political Science Review 105(4):702-716

Skarbek D (2014) The Social Order of the Underworld: How Prison Gangs Govern the American Penal System. Oxford University Press, Oxford

Skarbek D (2016) Covenants without the Sword? Comparing Prison Self-Governance Globally. American Political Science Review. 110(4):845-862

Smith W (2014) Inside Man: Loyalists of Long Kesh - The Untold Story. Colourpoint Books, Newtownards

Smithson H, Monchuk L, Armitage R (2012) Gang Member: Who Says? Definitional and Structural Issues. In: Esbensen FA, Maxson CL (eds) Youth Gangs in International Perspective: Results from the Eurogang Program of Research. Springer, New York

Steinberg J (2004) The Number: One Man's Search for Identity in the Cape Underworld and Prison Gangs. Jonathan Ball Publishers, London

Sykes GM (1958) The Society of Captives: A Study of a Maximum Security Prison. Princeton University Press, New York

Sykes G, Messinger S (1960) The Inmate Social System. In: Clonard RA, Clemmer DR, Grosser GH, McCleery R, Ohlin LE, Sykes GE, Messinger SE (eds) Theoretical Studies in Social Organization of the Prison. Social Science Research Council, New York

Tilly C (1985) War Making and State Making as Organised Crime. In: Evansm P, Rueschemeyer D, Skocpol T (eds) Bringing the State Back In. Cambridge University Press, Cambridge

Ugelvik T, Dullum J (2012) Penal Exceptionalism? Nordic Prison Policy and Practice. Routledge, London

UNDOC (2012) National strategy for the development of the penal execution (Prison) system of the Kyrgyz Republic for 2012-2016. Available at https://www.unodc.org/documents/centralasia/PrisonReform/National_ Prison_Reform_Strategy_Unofficial_Translation.pdf (Accessed: $19^{\text {th }}$ December 2017)

US Department of State (2016) Kyrgyz Republic 2016 Human Rights Report. Available at https://www.state. gov/documents/organization/265752.pdf (Accessed: $19^{\text {th }}$ December 2017)

Varese F (2001) The Russian Mafia: Private Protection in a New Market Economy. Oxford University Press, Oxford Varese F (2010) Organized Crime. Routledge, London

Viola L (2007) The Unknown Gulag: The Lost World of Stalin's Special Settlements. Oxford University Press Wacquant L (2001) Deadly symbiosis: When Ghetto and Prison Meet and Mesh. Punishment \& Society 3(1):95-133 Weerman FM, Maxson CL, Esbensen FA, Aldridge J, Medina J, Gemert F (2009) Eurogang Program Manual: Background, Development and Use of the Eurogang Instruments in Multi-Site, Multi-Method Comparative Research. Available at https:/www.umsl.edu/ccj/Eurogang/EurogangManual.pdf (Accessed: 8 February 2018)

Williamson JC (2015) United States Marshals Service. The Encyclopedia of Crime and Punishment. Wiley Publishing, London

Winterdyk J, Ruddell R (2010) Managing prison gangs: results from a survey of U.S. Prison Systems. J Crim Just 38(4):730-736

Wood J (2006) Gang activity in english prisons: the prisoners' perspective. Psychol Crime Law 12(6):605-617 